First Peoples Child \& Family Review

An Interdisciplinary Journal Honouring the Voices, Perspectives, and Knowledges of

First Peoples through Research, Critical Analyses, Stories, Standpoints and Media

Reviews

\title{
Symbols and Strategies: Acts of Métis Resistance - Using the List of Rights as a Framework for the Reclamation of Indigenous Child Welfare in British Columbia and Canada
}

\section{Daleen Adele Thomas}

Volume 5, Number 1, 2010

URI: https://id.erudit.org/iderudit/1069065ar

DOI: https://doi.org/10.7202/1069065ar

See table of contents

Publisher(s)

First Nations Child and Family Caring Society of Canada

\section{ISSN}

1708-489X (print)

2293-6610 (digital)

Explore this journal

Cite this article

Thomas, D. (2010). Symbols and Strategies: Acts of Métis Resistance - Using the List of Rights as a Framework for the Reclamation of Indigenous Child Welfare in British Columbia and Canada. First Peoples Child \& Family Review, 5(1),

86-95. https://doi.org/10.7202/1069065ar

\section{Article abstract}

This article engages the reader in comparing the Métis List of Rights, originally authored by Louis Riel, with the current state of Indigenous child welfare in British Columbia and Canada. The relationship between children's resiliency and cultural resiliency is explored. Using a critical lens, a framework defining the progression of social regulation is presented. This paper begins by setting out the framework with its accompanying nine aspects: profit, competition, self-interest, justice, rights, duties, love, compassion and devotion. The discussion acknowledges children as sacred which allows us to move beyond conservative and socialist ideals. Then there is a discussion on the aspects of the Métis List of Rights with comments respecting the symbolic and literal application of the aspects to reclaiming Indigenous child welfare. Finally the article ends with recommendations for holistic pathway for reform.
This document is protected by copyright law. Use of the services of Érudit (including reproduction) is subject to its terms and conditions, which can be viewed online.

https://apropos.erudit.org/en/users/policy-on-use/ 


\section{Symbols and Strategies: Acts of Métis Resistance - Using the List of Rights as a Framework for the Reclamation of Indigenous Child Welfare in British Columbia and Canada}

\section{Daleen Adele Thomas ${ }^{a}$}

\begin{abstract}
a LL.B. (Victoria), B.A. (Lethbridge). Daleen is an aspiring lawyer. She is the Community Representative on the Greater Victoria Family Court and Youth Justice Committee and the Vancouver Island Health Authority's Paediatrics Ethics Committee. She has authored several papers with respect to Indigenous People and Society/Law. She also contributes to a Wellness Ezine called Living True as "Momma Day." Recently she has been a guest speaker at engagements such as, Between Two Worlds, Ethics and Culture (Quw-utsun Cultural and Conference Centre, Duncan, BC) (panelist) and SD 63 Cultural Planning Review (Tsartlip Band Office, Brentwood Bay, BC) (Métis Representative). In 2009, Ms. Thomas was the Guest Lecturer for Tim Richards, Social Welfare Law, she presented a discussion on cultural safety and awareness when working in the area of social welfare. Currently, Daleen lives in Brentwood Bay, BC with her family and several other critters.
\end{abstract}

\section{Background}

In June 2009, contracted to complete a large literature review on social welfare reform and Indigenous children, I holistically examined contemporary changes, (still underway), involving Indigenous children and families in Canada and more specifically, British Columbia. While researching the category of "Neglect," I became interested in the parallels between the aspects of a child's resiliency and those of cultural, specifically Métis, resistance. Integrating my analytic observations with indigenous child welfare policies in British Columbia and Canada, I posed the question; if resiliency in children resembled cultural resiliency, what could be learned from the history of the Métis Nation, specifically it's successes in resisting colonization?

Questions or correspondence concerning this article may be addressed to:

dathomas@uvic.ca

\begin{abstract}
This article engages the reader in comparing the Métis List of Rights, originally authored by Louis Riel, with the current state of Indigenous child welfare in British Columbia and Canada. The relationship between children's resiliency and cultural resiliency is explored. Using a critical lens, a framework defining the progression of social regulation is presented. This paper begins by setting out the framework with its accompanying nine aspects: profit, competition, self-interest, justice, rights, duties, love, compassion and devotion. The discussion acknowledges children as sacred which allows us to move beyond conservative and socialist ideals. Then there is a discussion on the aspects of the Métis List of Rights with comments respecting the symbolic and literal application of the aspects to reclaiming Indigenous child welfare. Finally the article ends with recommendations for an holistic pathway for reform.
\end{abstract}

As social evolution, or revolution, of the Métis Nation continues, examples of Métis resistance to imposed policies and ideologies flourish. Through an examination of the Nation's definitional platforms, in particular the List of Métis Rights, symbolic and conceptual similarities between the List and social work practice are identified. I asked myself, what aspects of the Métis movement could we adapt to the child and family welfare movement? In order to answer this question, I introduce my analytic framework, briefly describe the discourse of holistic movement in society, provide insights with respect to the List of Métis Rights, and finally, propose a path forward.

Indigenous perceptions of child welfare acknowledge children as sacred and the corresponding responsibility to honour their sacredness. This is not a new perspective, rather, it re-captures traditional values as we move forward. Through this recognition, I hope to avoid the "trait" trap. Instead of trying

\footnotetext{
1 My preference is the discourse captured in an essay by Subhash Sharma, "A Vedic Integration of Transitions in Management Thought: Towards Transcendental Management" (2005) 1 Gurukul Business Review at 5 (Sharma, 2005).
} 
to define what traits people and nations possess, this process attempts to examine the relationships between the oppressor and the oppressed. Throughout my paper, I have utilized the presumptions inherent in anti-oppressive practice models to define oppressor/colonizer and oppressed/colonized. The danger of this approach may be the readers who are not Indigenous may feel they (by default) are the oppressor. The purpose of the use of this language is that by examining the historical system and parts of the current system reminiscent of it, allows our examination of the problem to transcend these dichotomous relationships on the path forward ${ }^{2}$.

To view a child as sacred is to see children as human beings that deserve love and compassion. They are not a number, or a resource in a 'for profit' childcare model and foster care system. Conceptualizing children as sacred recognizes their needs for holistic care, which requires more than "healthy parenting relationships". We must focus on children's wellness in respects to their mind, body, spirit and physical wellness. In addressing these rights holistically, we acknowledge familial bonds, cultural identity, and spirituality, as integrated aspects of wellness. In general, this form of wellness speaks to Indigenous perspectives and in most cases not a contemporary Canadian or Provincial government and institutional standards.

In practice, what would holistic solutions in child welfare and legal reforms look like? In order to answer that question I sketch out a holistic framework and then I examine the tenets of the List of Métis Rights. It is my hope that the resiliency evident in the List of Métis Rights will be closely examined for their significance by the reader. In requesting this 'deep reading' I also challenge the reader to apply their observations to policies of indigenous child welfare reform. I have chosen this author-reader engagement and reflection format to stimulate a discussion of new paths forward while honouring the connection between micro-individual resiliency and macrocommunity resilience.

\section{About the Author}

My name is Daleen Adele Thomas. I am the great great great great great (x5) granddaughter of Nostisho Nestichio ${ }^{3,4}$, daughter of Isaac Batt, the first white Hudson's Bay employee killed by an "Indian" in present day Saskatchewan in 1791. In that same year, Nestichio legally married James Spence Sr. at the York Factory, Manitoba after marrying according to Indian

2 If the terminology of colonizer or oppressor triggers something in you, further individual examination of why this is happening is essential when moving forward as part of the reclamation process.

3 Nestichio's mother was a "full-blood indian", this makes Nestichio the first "mixed-blood" offspring on the native branch of my family tree.

4 Genealogy notes from Dianna Mortenson, http://www.ojibwe.info/ Ojibwe/HTML/notes/n00000ic.htm\#I27718 "her name is a Cree name,

"Nestichiwub," meaning "three persons in one," i.e. that she has three guardian spirits." custom "at least as early as the 1780's (Brown, 1980)". In 1793, the Hudson's Bay Company placed James Sr. in charge of the Buckingham House at York Factory. I am located seven generations later in direct descent from Nostisho Nestichio.

Samuel Hearne's journal notes that one of the wives of Isaac Batt", she was "forced to suckle a Young bear" (Bingley, 1803) after losing a child. For me, this genealogical artefact represents the extent to which Indigenous women's lives were documented and scrutinized by the colonist. My great grandmothers suckling of a bear cub may bring strong disdain and confusion from the "civilized" community. However, we know from indigenous narratives and oral history that the domestication of bears served a specific purpose within a particular society. ${ }^{6}$ The ways in which we interpret the story depend on our cultural knowledge and our relationship with both the story and its characters.

A Métis or Indian wife, often labelled the "country wife" (Brown, 1980, p. 76), 7 gave life to new generations of mixed blood children. Within the family, mother acted as cultural broker, taking on such roles as peacekeeper, mediator and interpreter (Van Kirk, 1983). As the person responsible for her children's socialization processes, the Métis mother protected them and her Indian family, finding commonalities between cultures and creating a path for Canada to move forward. From a young age, I have also felt compelled to reconcile the multiple cultures that inform me, and to find harmony within and amongst them.

This paper flows from two presumptions and two objectives. The first presumption is that the area of social welfare is itself $\mathrm{r} / \mathrm{evolving}^{8}$ and dynamic. In this paper, I elaborate nine re-volutionary aspects. Not only is this a dynamic area, but I maintain that current shifts reveal a transcendental or holistic movement in society, and that this shifting is represented in the reclamation and reconciliation of our Indigenous People. One example is the Human Rights claim, First Nations Child \& Family Caring Society of Canada and the Assembly of First Nations v. Attorney General of Canada (representing the Minister of Indian and Northern Affairs) (in courts January 18 - 20, 2010). ${ }^{9}$ If successful, this claim could positively impact our people and our treasured children within weeks or months. Another transcendental development in our community is the potential ${ }^{10}$ of Jordan's Principle.

5 There is speculation that there were more than one.

6 If any readers have any stories or comments please contact the author dathomas@uvic.ca.

7 Means, married according to Indian custom. "I was married after the custom of the country myself...When I took a wife as above mentioned, I made a solemn promise to her father to live with her and treat her as my wife as long as we both lived" (Johnstone et al. v. Connolly 1869: 285-286). 8 The hyphenation of this word indicates the ability of the reader to substitute evolution or revolution depending on their belief.

9 Be a witness http://www.fnwitness.cal

10 "Potential" because we have yet to see the widespread, proactive, 
The second presumption flows from the love, compassion and devotion that inform the spiritual relationship we have with Mother Earth and other living beings. These relationships are not located in a single religion. Rather they arise from a spiritual principle that evokes the recognition that Mother Earth is a living being at the centre of the spiritual/religious realm. This position confronts the official discourse on Nature in the Judeo-Christian paradigm; that the Earth is a non-living, inanimate resource provided by God for the use of man - currently for exploitation and profit. Underlying the centrality of the Earth's spiritual importance, are new tenets that acknowledge Earth's central role, such as principles of sustainability, especially with respect to intergenerational and inter-societal equities (Cordonnier Seger, 2006).

Holistic reforms and pantheisms reject the notion that children can be "owned" by any "one" person or in some cases, families. Instead, they insist upon a respect for all aspects of the child, themselves, their siblings, their parents, their uncles and aunties, their grandmas and grandpas, their clan, their community, and their nation. ${ }^{11}$ The operation of pantheism in child welfare would demand the interwoven healing needed for our people, our families, our communities and Mother Earth. An elder from Taku River Tlingit once told me: "We find poisoning in our people, and in our rivers."

My two objectives focus on the Métis List of Rights and the areas of child welfare reform that will benefit from that framework. I have written this exchange in a simplified manner. It is my hope that you (the reader) will contemplate each subsection of Rights and identify additional uses for these Métis symbols and strategies of resistance. Not coincidentally, I hope that you will learn a bit about Métis history as well.

\section{The Ground Work - Theory of Transcendental or Holistic Movement of Community}

The idea of an evolving movement in society is captured in Subhash Sharma, "A Vedic Integration of Transitions in Management Thought: Towards Transcendental Management" (Sharma, 2005). Although Sharma published his article with a focus on Management philosophy, I adopted this transcendental theory in my major paper at law school with respect to Indigenous People and a Right to Set ${ }^{12}$. The concepts are simple and easily transfer to other areas of societal governance, such as child and family welfare and the State.

This transcendental movement in society is grounded in an analysis of the r/evolution of social thought and

routine use of the Principle.

11 I note that this list is not exhaustive.

12 Yet unpublished, written in Summer 2008, supervised by John Borrows. management that shifts our society from its intense adherence to capitalist ideals alone, to one that is also considerate of both socialist and holistic or transcendental ideals. The value shift that accompanies this ideological shift moves from capitalism, which 'considers human beings as 'economic units' and is rooted in Adam Smith's ${ }^{13}$ philosophy of Profit, Competition \& Self-Interest (PCS) (Sharma, 2005, p. 5)," to the transcendental tradition which "considers human beings more than social beings and considers them as a bundle of qualities. Some ... consider human beings as 'divine beings'” (Sharma, 2005, p. 5). This focus is "rooted in the philosophy of Love, Compassion and Devotion" (Sharma, 2005, p. 5) and is not limited to any one "religious" or "spiritual" doctrine ${ }^{14}$.

The socialist, or intermediary philosophy, tends to focus on "human beings as social beings for whose benefit society exists (Sharma, 2005, p. 5)" and is "rooted in the philosophy of Justice, Rights and Duties (JRD)” (Sharma, 2005, p. 5). In my estimation, the recent transformations in Canadian Indigenous Child and Family Welfare focus on the Justice, Rights and Duties of the family, child and social worker. It is my hope this paper will provide the additional dimension of how to develop holistic pathways forward in a transcendental and holistic manner.

An example of how my theory views child and family welfare is to visualize a continuum of colonization at one end and self-government at the other end. Initially, child and family welfare in Canada appeared to be concerned primarily with the self-interest or colonialist agenda of the State. Grounding values were capitalist in nature, that is to say they focused on Profit, Competition and Self-Interest. At the other end of the continuum, we see (still the primary current phase), the Rights and Duties of children, parents, grandparents and communities. The values of this socialist perspective demand the consideration of the Duty of the State, hopefully finding Justice in the solutions.

A transcendental theory of Indigenous child welfare in Canada (and resulting long-term solutions), requires more than consideration of those first six aspects (Profit, Competition, Self-Interest, Rights, Duties, Justice). It also demands intentional values of love, compassion and devotion incorporating both ends of the spectrum. This changes the continuum into a triangular relationship and places the three categories in relation to one another.

\footnotetext{
13 It should also be noted that Adam Smith's Eurocentric classification of human societies presented in his 1766 "Private Law" lectures, correlated stages of development of the society with the degree of sovereignty they should have over their lands. Intentionally he excepted Indians from his order of hunters, pastoralists, farmers and businessmen. Penikett, Supra note 25 at 32.

14 It is vital that the spirituality/religion underlying this movement is not exclusive in doctrine supremacy and is holistic in nature.
} 


\section{Métis Resistance and Louis Riel}

"It is almost refreshing to notice the ability, the energy, the determination which up to this point has characterized all the movements of the originator and mainspring of the movement, M. Louis Riel. One hates so much to see

a thing bungled that even resistance, although it borders upon rebellion, becomes respectable when it is carried out with courage, energy and decision."

$$
\begin{array}{r}
\text { (Captain W.F. Butler, }{ }^{15} \text { Riel: } \\
\text { A Life of Revolution, Maggie Siggins, p. 171) }
\end{array}
$$

The area of children's care has entered a time of change. Awareness of the plight of our Indigenous children demands we no longer sit in silence while the oppressor prepares its inventories/assessments, its guidelines and implements its own practice. The time has come to reclaim our Nations by protecting our sacred children, who need to be safe and healthy. Next to protecting our children, writing our own guidelines, and implementing and funding them, have become the most difficult tasks at hand.

A definition of resilience assists in identifying the acts that embody it. Luthar, Cicchetti, and Becker (2000), suggest a two part definition of resilience: 1) has there been exposure to "significant threat or adversity" (p. 543) and 2) is the result a "positive adaptation despite major assaults on the developmental process" (p. 543)? With this definition in hand, we can ask ourselves: What aspects of the actions of the Métis and Louis Riel transcended the "significant threat or adversity" (Luthar, Cicchetti \& Becker, 2000, p. 543)? While answering this question, attention to what threats and adversities they (the Métis) have faced (are facing) and how they have positively adapted to major assaults on their Nation and movement, will provide a complete picture of the culture of Métis resistance. The essence of this culture is vital for Indigenous reclamation movements.

Before I focus on the List of Demands and their aspects, it is important to recognize Louis Riel as one of the first true Canadian heroes. ${ }^{16}$ At the very least, the diversity of who he was and what he stood for, enforced an acknowledgement of our diverse demands on the Canadian government that has greatly benefitted our Nation. Without him, we, the Métis people and our Land, may not have entered the Canadian Confederation.

"The very essence of Louis Riel is contradiction. He was a handsome, smartly dressed, highly educated prude who enthralled his adoring constituency, the illiterate,

$\overline{15}$ It is noted in Siggins biography of Riel that Captain Butler "was hardly a friend of the Métis; in fact he had nothing but contempt for anybody who wasn't of British stock" (Siggins, 171).

16 This recognition includes the respect for any inner struggles Riel may or may not have had with respect to mental illness and/or disability. risk-taking, pleasure-loving Métis buffalo hunters. His was a conservative political philosophy and yet he led a desperate, violent rebellion against the very political establishment he had once supported.

He was a devout Catholic, yet his heart-felt religion was laced with Indian spiritualism, and he didn't hesitate to

thumb his nose at meddling clergy, who promptly labelled him a heretic. Most important: only one branch of the Riel family shows Indian heritage - his paternal grandmother was a mixed-blood, all his other ancestors were FrenchCanadian - and yet he symbolizes to this day the courage, pride and accomplishments of what is now seen as the Métis golden age." (emphasis mine) (Siggins, 1994, p. 3)

In 1869, Riel composed a List of 14 items to be incorporated into a List of Rights for the Métis People of the proposed Province of Assiniboia. ${ }^{17}$ Peers and opponents (both English and French) reviewed this list. Revised at least four times, Canada received the third and last revision of the List on March 22, 1870. Below, I reproduce the complete List of Rights of Riel's Provisional Government, 1870. Offering the List in its entirety before I examine it in subsections, facilitates the ability of the reader to feel the depth of its considerations and design. In other papers, and in books on the Métis, this list is consistently relegated to the Appendix portion of the paper. This document is not a footnote; it is the conversation. Therefore, the list is embedded in this discussion and must be read in its entirety.

The principles of this list were incorporated into the Manitoba Act, May 12, 1870. This is analogous to the state of child welfare in British Columbia where Indigenous policy makers are being asked to construct policy that could potentially guide the law. The List of Métis Rights is a concrete example of policy leading law.

LIST OF RIGHTS (Congress of Aboriginal People (CAP online), Appendix III - List of Rights - Metis Provisional Government 1870)

- 1. THAT the Territories heretofore known as Rupert's Land and North-West, shall not enter into the Confederation of the Dominion of Canada, except as a Province; to be styled and known as the Province of Assiniboia, and with all the rights and privileges common to the different Provinces of the Dominion.

- 11. THAT we have two Representatives in the Senate, and four in the House of Commons of Canada, until such time as an increase of population entitle the Province to a greater Representation.

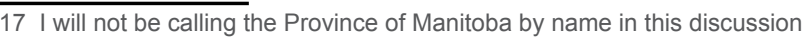
as it is clear in the List of Rights, the Metis wanted the Province to be called Assiniboia. I have not researched this significance but there is a strong commitment in our culture to respect names and the importance of what we call our own ideas and places. 


\section{Symbols and Strategies: Acts of Métis Resistance}

- 111. THAT the Province of Assiniboia shall not be held liable at any time for any portion of the Public debt of the Dominion contracted before the date the said Province shall have entered the Confederation, unless the said Province shall have first received from the Dominion the full amount for which the said Province is to be held liable.

- IV. THAT the sum of Eighty Thousand $(80,000)$ dollars be paid annually by the Dominion Government to the local Legislature of this Province.

- V.THAT all properties, rights and privileges engaged by the people of this Province, up to the date of our entering into the Confederation, be respected; and that the arrangement and confirmation of all customs, usages and privileges be left exclusively to the local Legislature.

- Vl. THAT during the term of five years, the Province of Assiniboia shall not be subjected to any direct taxation, except such as may be imposed by the local Legislature, for municipal or local purposes.

- Vll. THAT a sum of money equal to eighty cents per head of the population of this Province, be paid annually by the Canadian Government to the local Legislature of the said Province; until such time as the said population shall have reached six hundred thousand.

- V1ll. THAT the local Legislature shall have the right to determine the qualification of members to represent this Province in the Parliament of Canada and in the local Legislature.

- IX. THAT in this Province, with the exception of uncivilized and unsettled Indians, every male native citizen who has attained the age of twenty-one years, and every foreigner being a British subject, who has attained the same age and has resided three years in the Province, and is a householder; and ever foreigner, other than a British subject, who has resided here during the same period, being a householder and having taken the oath of allegiance, shall be entitled to vote at the election of members for the local Legislature and for the Canadian Parliament. It being understood that this article be subject to amendment exclusively by the local Legislature.

- X. THAT the bargain of the Hudson's Bay Company with respect to the transfer of the Government of this country to the Dominion of Canada, be annulled; so far as it interferes with the rights of the people of Assiniboia, and so far as it would affect our future relations with Canada.

- Xl. THAT the local Legislature of the Province of Assiniboia shall have full control over all the public lands of the Province, and the right to annul all acts or arrangements, made, or entered into, with reference to the public lands of Rupert's Land, and the North West now called the Province of Assiniboia.

- Xll. THAT the Government of Canada appoint a Commission of Engineers to explore the various districts of the Province of Assiniboia, and to lay before the local Legislature a report of the mineral wealth of the Province, within five years from the date of our entering into Confederation.

- XIII. THAT treaties be concluded between Canada and the different Indian tribes of the Province of Assiniboia, by and with the advice and cooperation of the local Legislature of this Province.

- XIV. THAT an uninterrupted steam communication from Lake Superior to Fort Garry be guaranteed, to be completed within the space of five years.

- XV.THAT all public buildings, bridges, roads and other public works, be at the cost of the Dominion Treasury.

- XVI. THAT the English and French languages be common in the Legislature and in the Courts, and that all public documents, as well as all acts of the Legislature be published in both languages.

- XVII. THAT whereas the French and English speaking people of Assiniboia are so equally divided as to number, yet so united in their interests and so connected by commerce, family connections and other political and social relations, that it has, happily, been found impossible to bring them into hostile collision, - although repeated attempts have been made by designing strangers, for reasons known to themselves, to bring about so ruinous and disastrous an event; - and whereas after all the troubles and apparent dissentions of the past, - the result of misunderstanding among themselves; they have - as soon as the evil agencies referred to above were removed, - become as united and friendly as ever; - therefore, as a means to strengthen this union and friendly feeling among all classes, we deem it expedient and advisable, - That the Lieutenant-Governor, who may be appointed for the Province of Assiniboia, should be familiar with both the French and English languages.

- XVIII. THAT the Judge of the Supreme Court speak the English and French Languages.

- XIX. THAT all debts contracted by the Provisional Government of the Territory of the North-West, now called Assiniboia, in consequence of the illegal and inconsiderate measures adopted by Canadian officials to bring about a civil war in our midst, be paid out of the Dominion Treasury; and that none of the members of the Provisional Government, or any of those acting under them, be in any way held liable or responsible with regard to the movement, or any of the actions which led to the present negotiations.

- XX. THAT in view of the present exceptional position of Assiniboia, duties upon goods imported into the Province, shall, except in the case of spirituous liquors, continue as at present for at least three years from the date of our entering the Confederation and for such further time as may elapse until there be uninterrupted railroad communication between Winnipeg and St. Paul and also steam communication between Winnipeg and Lake Superior. 


\section{Aspects of the Métis List of Rights, 1869 - 70}

Next, we will examine in part, the contents of the List. For ease of discussion, I have chosen to use subsections identified by the Dictionary of Canadian Biography Online ("CBO"). I offer the $\mathrm{CBO}$ subsection as a locater, and comments on the content and implications of the section follow. A piece of scrap paper might be handy to record any thoughts or relationships these strategies or demands elicit from the reader.

"that a province be established, not liable for any portion of the public debt of the dominion; (Laval, 2009)"

Ensuring that the establishment of the province of Assiniboia would not be accompanied by inherited debt was motivated by self-interest. The practical message of this provision is not to assume any debt when reclaiming our children and families through new structures and policies of child and family welfare. Symbolically there is a refusal to assume the negative aspects of the current child welfare system in British Columbia when taking these fresh new steps. What aspects of our current system do we not want to integrate in the future system?

"that during a term of five years it not be subject to any direct taxation except for municipal purposes; (Laval, 2009)"

This provision served a couple of purposes for the Métis. In one sense, it provided social protection for the Métis during the initial years of the "amalgamation". In another, it ensured that the oppressoe coluld not use the tool of taxation as a weapon. This strategy, when implemented in reforming other acts of decolonization (such as child welfare reform), requires us to ask, which weapons or tools of the oppressor cause us (and our communities) the most amount of societal damage? One example is less reliance on the operation of the court system and an assumption on an alternative family circle (case conferencing) as the norm. This will make family wellness plans more relevant and less costly.

"that a sum equal to 80 cents per head be paid annually to the province by the Canadian government; (Laval, 2009)"

This provision was squarely rooted in a conservative ideology, centred in providing funding to the Métis people directly proportional to the number of Métis in the province. This formula represents a tangible equation for funding. The Métis placed an additional, important stipulation on this money. Once the population of Assiniboia reached six hundred thousand, the sum was to cease being paid. The question we can ask ourselves is, at what point, which milestones, can we fully fund our own child and family services? Can we or should we have the responsibility in the future to fully fund, or should the Government of Canada and British Columbia forever hold a stake in the wellbeing of all it's citizens?

In a more symbolic sense, it asks us to discover our touchstones in our own communities? ${ }^{18}$ How will we identify our successes, and our/or missed opportunities?

"that it have control of the public lands; (Laval, 2009)

On one hand, this codicil appears to be firmly selfinterested. At the time this list was written, settlers were homesteading on historic Métis lots and claiming them for their own. The question of who owned the land, and/or who could settle the land, had become the fire in the belly of the Resistance. This statement, simple and short, demands that the people of the Assiniboia, the Métis, retain, reclaim or remain the owners, of the lands.

Can we ignore the significance of our connection to the land while we attempt to resolve the issues of child and family welfare in British Columbia? How, if one believes in, and lives, our physical, religious and spiritual connection to the land, can we heal our children and families, while our "rights" to the land are neither codified nor declared? In a reciprocal manner, how does our Mother's health affect the health of our children and ourselves? Riel found the answers to these questions in all members of mixed people. Our answers lie with the members of our community. The Elders will have vital input, the parents and middle aged will have input, and so will the children. Who are the stakeholders?

On a macro level, this proposition asks us to recontemplate the control of our Lands. On a micro-level, it might be asking us to set up presumptions of home ownership in the names of our children when relationships dissolve. This form of centering the children within the dispute (in family law) is called nesting. When parents are unable to resolve marital conflict, the non-custodial parent removes him/herself from the domicile, leaving the custodial parent and children in their familial home. With visitations, the non-visiting parent leaves the home. The result is less confusion and disruption in the children's lives with a commitment to providing as normal a life as possible for those permanently affected by marital dysfunction or family violence.

On the other hand, this demand reflects justice, rights and duties. It clarifies exactly who will hold public lands in the province. Importantly, (this is?) there is yet another dimension to land - aboriginal spirituality. To me, this demand is deeply rooted in transcendental and holistic notions which, 18 This is in reference to the Touchstones of Hope project already underway in child welfare reform. 
when acknowledged, will assist in a true wellness of our People and Nations. Sadly, our society defines the role of our governments as one concerned with capitalism, corporatism and conservative ideologies. It is not within the scope of the capitalist model to consider love, compassion and devotion. This does not mean we have to accept the constraints of the government. We have the power to define how we are governed.

Demanding access for our children to their homelands so that their connection to their People and Nation remain strong is a logical extension of our requests. In the same way that we should not be denying stability to our children and families in transition, we cannot ignore the significance of land and our connection to it when we speak of reforming child and family services in Canada.

\section{"that treaties with Indians accord with the wishes of} the province; (Laval, 2009)"

This provision was in fact stated, "by and with the advice and co-operation" of the Government of Canada, treaties would be settled with the Indians. This signifies the importance of the duty of Government (of the duty of the government of Assiniboia, with the advice and cooperation of Canada, to enact treaties with First Nations) to reach Treaties with the Indians. The strongest element of this provision is it's demand for the unity of process resolution for all Indigenous people of Canada, Métis and Aboriginal. A united front amongst Indigenous peoples in Canada is much more powerful than piecemeal, antagonistic, competitive processes. True leaders in our communities will demand unity amongst Indigenous brothers and sisters.

It is disgraceful that this demand, made in 1870, has not been adequately realized by Canada or British Columbia. ${ }^{19}$ By remarking on this process in their List of Rights, the Métis are showing solidarity for their brothers and sisters. The question we can ask ourselves in reforming child and family services is, which other processes of healing for our people can we voice support for while negotiating our own change?

We should be reminded that while we are looking forward to change in this specific area, we can also look sideways and publically support others struggling next to us. Areas of reform that come to mind with respect to this tactic are violence against women, fetal alcohol syndrome and effects (spectrum disorder), and residential school claims/healing. Statements for and against certain proposals, law reform, and proposed cuts to funding, can be (and should be) made publically. There are many tactics available to realize this goal, we can send out news

19 Only a handful of Treaties exist in British Columbia, the majority of them the Douglas Treaties on Vancouver Island. releases, we can publish position papers, and resolutions can be made at every level of governance. ${ }^{20}$

Eventually, when agreements are determined to be illegal by our own Nation's lawyers, we should be initiating (and have been, in limited cases), legal action against the oppressor. I believe firmly we should seek a legal opinion on the obligations of Canada with respect to the United Nations Convention on the Rights of the Child, and other international legal instruments and laws (including customary laws). This will inform us as to the obligations Canada has for all Canadian children and the additional or special obligations for its Indigenous children.

\section{" that uninterrupted steam communication from} Upper Fort Garry to Lake Superior be provided and that all public buildings, bridges, roads, and other public works be paid for by the federal government; (Laval, 2009)"

The reference to provision of railway service from and to parts of the Métis territory and other various essential routes of transportation, highlight the fundamental necessity for the Métis to travel freely throughout Assiniboia. The importance of infrastructure to the success of the Métis as an independent Nation within Canada lies in its ability to facilitate successful capitalist trade, and its fundamental role in the cohesion of community and strength of families. Movement also has sacred and historical elements for the Métis. ${ }^{21}$ The ability to travel had kept the citizens of Métis Nations safe from the grip of the colonizer for nearly a hundred years. Indeed, movement underlies the current day spread of the Métis throughout present day Canada.

This provision is holistic as it addresses all three paradigm shifts: capitalism, socialism and transcendentalism.

Questions to ask ourselves today are; considering our agenda of reform in child welfare, what infrastructure is essential? How can we demand preservation of those aspects of the system currently working well, and those required for full independence or self-government? Which aspects of our relationship with the colonizer have protected us? How can we retain those? The tactic of colonization; divide and conquer, plays a significant role in this discussion. For a more cohesive and permanent healing of our communities, I believe it is vital for First Nations to come together and share their own successes together with challenges. On a larger level, we could

\footnotetext{
20 In much the same way we see municipal governments making resolutions at their Provincial level meetings, our Nations can come together in Assemblies and Coalitions to publically endorse or speak against any relevant initiative.

21 Seasonal communities and following the buffalo are two examples of this but it is much greater than this.
} 
achieve our mutual goals through a collaboration on funding applications, and the sharing of healing resources.

"that the English and French languages be used in the provincial legislature and courts and in all public documents and acts; that the lieutenant governor and the judge of the superior court should be familiar with both the English and the French languages; (Laval, 2009)"

The Métis were in fact, at this point in time, comprised of two separate mixed blood communities: the Métis of the French and the Half-breeds of the (Scots) English. In fact many of the half-breeds were not "English" per se, but rather (In all: far more (tribal) Highland Scots than Orkney men the dominant combinations are Cree or Ojibwa with French or Scots) Orkney men. (My family falls primarily into this group. Just footnote this observation) As Riel reformed his List of Rights, with input from other groups and individuals, he intentionally presented this List to both an English speaking Métis group and a French speaking Métis group. I argue that this collaborative, transcendental approach to document design informs the rationale underlyinh the acceptance of many of its tenets into the Manitoba Act. It is my belief that this deliberate, intentional building of a document with equal participation, canvassing all affected, is one of the most poignant aspects of the List.

The significance of language, both literally and figuratively, also cannot be ignored. Reclaiming our Ways and ourselves requires reclaiming our languages. Can we request family circles spoke in our native language? Can we tell our children our feelings in our own language? Can they understand?

In a symbolic sense, modes of communication, art, singing, ceremony, drumming, are the languages of our people. When we design our models for child welfare, in what language will we speak of them? In the North, the Carcross First Nation has incorporated language, traditional law, oral teachings and ritual/ ceremony into one document. The result is a Family Act of codified tribal law which is intended to guide its own citizens, the social workers/lawyers, and the State.

When building new practice standards we can ask: Who are the parties affected by our reform? Has everyone had input (including children, elders, government workers)? From a content perspective we would ask, what literal language should we employ? How do we define our keywords? What is the meaning of our words?

"that an amnesty be extended to all members of the provisional government and its servants; (Laval, 2009)”
This provision demands surrender of actions against "all members of the provisional government and its servants." This provides protection for those at the highest risk of retaliation from the Canadian government. We might ask ourselves, who in our communities are most at risk (from institution? Clarify and bring it home)? Who requires protection? How can we reclaim those already harmed by the colonizer's institutions, ideologies and social frameworks? How can we protect those who are victims of violence (this is doubly significant, because here you are protecting those who may have become violent due to institutions, ideologies etc, or have experienced violence at the hands of the state/institutions. Yet they are also members of our community who do violence to other members. These are questions of healing on multiple levels) or other forms of abuse?

One aspect of this provision is that a positive obligation is imposed on the government to provide amnesty to its people (it does not say "refrain from charging or arresting"). How can we charge our governments to protect those at the highest risk during reforms? For example, if a nation seeks custody of a child, how can we ensure that B.C. would consent and not oppose that suit in certain cases (or most cases)? Would British Columbia agree to provide our communities with information that would allow us to locate our genetic family members (who were removed in the past 50 years)? This provision addresses the potential occurrence of a feared outcome, thus it asks us to identify our fears. What is the worst that could happen? How do we prevent that?

"and that no further customs duties be imposed until there was uninterrupted railway communication between Winnipeg and St Paul. (Laval, 2009)"

This last provision again speaks to self-interest and preservation and is a conditional demand. It provides a benefit for Canada (imposing further custom duties) once the rail way is complete. What incentives can we bring to the table? How can we reward Canada and British Columbia with our success? What contingency requests would benefit our people?

\section{Additional Considerations}

It is interesting to note that once the third revised list was presented to Canada, two additional requests were added. This fourth List included, doubtless with Riel's and Tachés blessing, a provision for separate schools paralleling the system implemented in the province of Quebec, and outlined the structure for a provincial government" (Laval, 2009).

The integration of additional key requirements signals the necessity that the List be fluid and non-exhaustive. My research on these two elements does not extend to how each 
were defined in relationship to one another, but my imagination wonders; if government officials set out potential provincial government structures, did Riel (or his friend), use additional requirements for education as a lever with the government of Canada? In any case, the supplements to the original submitted list reveal that Riel remained attentive to the needs of his people, even after he had sought their input. In the end, his addition of the separate school clause ensured that a significant for the potential protection of culture and language existed within the State. Ironically, the history of the Métis people in Canada is nearly non-existent in our Province (BC).

The reading of the List in this article may represent a reader's first awareness of the Métis' contributions to Canada and our historically stipulated Rights. The nature of these demands illuminates aspects of healing that Riel and his community believed would heal their People, their Nation. Briefly, I have compared the symbols and strategies of this List with our own reforms and concerns. This is a difficult task. It is abstract and at times strained by the two differing ideal outcomes: 1) the Métis' achievement of Nationhood and 2) the Indigenous child achieving Personhood. ${ }^{22}$

In reality, these two movements dialectically speak to one another. On one hand, people live with splintered cultural and spiritual personalities/identities, on the other, children and families are fragmented by family dysfunction/unwellness and/ or lack of community wellness.

"I don't think that anyone, without having gone through the fire, can understand the feeling of being Métis.

Belonging to both, but in reality to neither. Growing up in Fort Norman in the 1950's, I went through the fire. White and Indian accepting you on the surface, but rejecting you from the heart and soul.

Imagine the feeling of a person being called a "Goddamned Halfbreed." So for a while we did what we thought was a smart thing: when with the Whites, we were White; when the Indian came, we became Indian, but this could only go on for so long without splitting ourselves apart trying to be two people."

Rick Hardy, former president of the Métis Association of the Northwest Territories at the Berger Inquiry (1974-77)

(Weinstein, 2007)

\section{Holistic Path Forward}

The holistic path forward in the evolution of social work respects all aspects of our societal movement: profit,

22 Also not canvassed in this paper but essential to the rights of the child are a right to counsel and a right to dignity. Both of which are classical components of Personhood (Margaret Jane Radin, Reinterpreting Property (Chicago: University of Chicago Press, 1993)). competition, self-interest, justice, rights, duties, love, compassion and devotion. Identifying these aspects assists us in transcending the antagonistic relationship between capitalist and socialist philosophy. If we deeply contemplate the relationship of children with their families and Nations as successful when defined by love, compassion and devotion, our infrastructure, both social and physical, takes on new dimensions. Riel's Métis Resistance stood for, (even for his critics) and defined courage, energy and devotion. Each of us has a task in this $\mathrm{r}$ / evolution, each of us holds part of the key in solving the problem of child and family welfare in our communities, our Province and our Country.

\section{Where do we find the Key?}

There is a new movement in the area of reforming Children's lives that demands the centering of Children. In his new book, Child Honoring, How to Turn this World Around, Raffi (yes, baby beluga Raffi!) proposes a societal revolution based on compassionate values. ${ }^{23}$ In Chapter 7 , Lorna B. Williams of the Lil'wat nation describes in detail what "Honoring All Life" looks like in practice. Looking through her own lens as a residential school survivor, she posits that intention, naming, tradition, play, ritual, and training are all essential in Lil'wat child-honoring practices. It is by "rebuild(ing) respectful caring societies" that our children will heal. She states on page 88 :
"Healthy, caring communities produce healthy, caring, responsible children. And healthy, caring, responsible people create healthy, caring communities. First Nations worked at living life in a respectful, responsible, relational manner by practicing humility and acknowledging that we are only a small part of a greater whole. When each child in a community is honored and treated in an honorable way, all life is honored. While we can not go back in time to relive the past, we can still learn from First Nations and other Indigenous people how they cared for and honored children to create healthy communities that cared for and honored all its members" (Cavoukian, 2006).

When we look to our communities, how do our Elders describe our traditional ways of caring for our children? What can we learn from other nations? The answers to these questions assist in building policy and legislation from the ground up, in a compassionate and culturally relevant way.

On October 11, 2001, Dr. Henrietta Mann (Elder, Mentor), gave a lecture at the University of Victoria. She is a respected Elder of the Cheyenne nation and holds many 23 I encourage everyone to read this book and I have written a book review available online at http://www.livingproofnutrition.com/files/Liv\%20 Tru\%20Fall\%202009\%20-\%20Final.pdf (pages 5-6). 


\section{First Peoples Child \& Family Review, Volume 5, Number 1, 2010}

distinctions including a Ph.D. I asked her this question: How do women who are of two worlds, those who may be returning to the teachings and find truth there, how do these women become leaders and remain true to all their ancestors? Dr. Mann replied:

"writing, reading, critically, analytically, the world is missing how to get along with each other. You can continue to be a bridge between them. Women are leaders, in the potlatch we take the leadership role, we share the wealth, and take care of the people. Remember that everything is in pairs ${ }^{24}$ and so are speech and silence."

She ended her response with the Spirit Powers in Council:

"The Council had the human power-potential because the humans could not handle it. The Council decided to not let humans run rampant. They first considered sinking it into the deepest part of the ocean. But one of the members said "Oh no, they are too resourceful, they will find it there."

The next suggestion was the deep earth, and hopefully they would learn how to use it before they found it. It was decided the humans would find it too easily there as well. The third suggestion was to place it on the highest mountain, but they all agreed the humans were clever enough, they would find it there as well. They asked the Great Spirit, we have this dilemma, Where should we hide the human power-potential?

The Great Spirit answered them: Humans will find it when they can handle it. Hide it within each of them, it is the last place they will look"(emphasis mine).

As we look forward on this path of reform, we acknowledge that a holistic approach requires a new framework. Using this self-reflective paradigm, we are able to justify grounding the movement in love, compassion and devotion. By transcending the supposed polar opposites of colonization and self-government, we will bring healing and wellness to our Indigenous families. These changes will transform child welfare while reclaiming the old ways.

All my relations.

\section{References}

Bingley, W. (1803). Animal Biography; or Ancedotes of the Lives, Manners and Economy, of the Animal Creation, arranged according to the system of Linnaeus. London: J. Adlord (original).

Brown, J. S. (1980). Strangers in Blood: Fur Trade Company Families in Indian Country. Vancouver: UBC Press.

24 Earlier Dr. Mann had spoke of pairs: male and female, death and life, and taught us that opposition or dichotomies (especially of the Cartesian variety) are not the true expression of these pairings. They are in relation with one another, not above or below one another.
Cavoukian, R. O. (2006). Child Honoring: How to Turn This World Around. Westport: Praegar Publishers. Available online at http://www. raffinews.com/files/child honouring/child honoring.pdf.

Congress of Aboriginal People (CAP online). (Appendix III - List of Rights - Metis Provisional Government 1870). Appendices of the 12979 Declaration of Metis and Indian Rights. Available online at http:// www.abo-peoples.org/Features/Declaration/decapd.html\#Append3

Cordonnier Seger, M.-C. a. (2006). Sustainable Development Law: Principles, Practices, \& Prospects. Oxford: Oxford University Press.

Laval, U. o. (2009). Riel, Louis 1881-1890 (Volume XI). Dictionary of Canadian Biography Online. Available online at http://www. biographi.ca/009004-119.01-e.php?BioId=39918.

Sharma, S. (2005). A Vedic Integration of Transitions in Management Thought: Towards Transcendental Management. Gurukul Business Review, 1 (Spring): 4-12.

Van Kirk, S. (1983). Many Tender Ties: Women in Fur-Trade, 1670-1870. Oklahoma: University of Oklahoma Press.

Weinstein, J. (2007). Quiet Revolution West - The Rebirth of Metis Nationalism. Calgary: Fifth House Ltd. 